\title{
The Need for Multifunctional Dikes in Europe - the MultiDikes Project Concept
}

\author{
Fokke Saathoff $^{1}$, Stefan Cantré2 ${ }^{2}$ Jan Olschewski ${ }^{3}$ \\ Chair of Geotechnics and Coastal Engineering, Universität Rostock, Germany \\ E-mails: 'Ifokke.saathoff@uni-rostock.de (corresponding author); ${ }^{2}$ stefan.cantre@uni-rostock.de; \\ 3jan.olschewski@uni-rostock.de
}

\begin{abstract}
In Europe there is a considerable interest in new flood protection technologies. In case of sea or river dikes, the land consumption is an important issue, particularly in densely populated urban areas or when other land uses are compromised. However, dikes are generally restricted to the function of flood protection. Only few additional functions are common, such as roads and pathways, which often cause difficulties regarding the planning, construction and maintenance of dikes. The concept of dikes with multiple functions is therefore new. Some innovations are being developed in the Netherlands while in Germany and the rest of Europe these concepts are yet unknown - with the exception of a new prospect regarding woody plants on dams and dikes which is under investigation in Austria and Germany. The lack of multifunctionality also results from the respective laws and regulations, in which the usability of dike construction is strongly restricted. This should be discussed and rethought.

The need for multifunctional dike concepts was approved by the German BMBF by funding a seed money project for a duration of 2 years. In this preparatory project, a larger EU cooperation project will be developed, in which the need for multifunctional flood protections and possible solutions will be investigated for different model regions around Europe. This paper presents the general concept and first ideas with the aim of finding additional partners and to start the discussion in the geotechnical research community.
\end{abstract}

Keywords: multifunctional dikes, multifunctional flood defences, dike construction technologies, European research.

Conference topic: Geoenvironmental engineering.

\section{Introduction}

Generally the function of sea and river dikes is restricted to the protection against floods (primary function). Common exceptions from this rule are roads or touristic pathways on the dike crest and the use of grass dikes as pasture (while the grazing lifestock is rather a measure of dike maintenance). There are only very few examples of other multifunctionalities when it comes to dikes, such as to allow woody plants on a dike for ecological reasons, while already small constructions such as concrete stairs to access the pathway on the top are seen as a threat to the stability during a storm surge or flooding event. Since the function of dikes is this restricted by law all over Europe, research on possible multifunctionalities is also neglectible. Only in the Netherlands, where climate change adaption strategies include the need for intensive reconstruction and heightening of dikes for which there may not be enough space particularly in urban areas, the idea to combine flood protection with other uses (parking, recreation, etc.) are blossoming.

Climate change and the associated predictions for rising sea levels and increased flooding due to concentrated precipitation periods in central Europe, however, will also lead to adaptions in other European regions. Therefore, there is a need to be prepared when additional flood protection is needed which rivals with other land uses in the respective areas. Also, this knowledge would be helpful today already when it comes to improving the ecological function and touristic usability of flood protection dikes.

\section{Project idea}

The MultiDikes project idea was born in 2014 during the final workshop of the DredgDikes project (Saathoff et al. 2015). The basic idea is to investigate and describe the opportunity of existing and prospective multifunctional dikes in Europe. In a first step, a preparatory project was granted by the German Federal Ministry for Education and Research BMBF with the aim of preparing an EU project on the topic of dike multifunctinoality either in an INTERREG or the Horizon 2020 frame.

The following justifications have been identified for the MultiDikes project:

- In Europe there is a considerable interest in new dike construction technologies because of the needed climate change adaption. This will lead to increased space requirements for flood protection structures, i.e dikes.

- In urban areas dikes rival with housing and infrastructure.

- In rural areas, dikes rival with touristic, agricultural and ecological uses as well as different aspects of nature conservation. 
In the first step, the following ideas have been summarised for the MultiDikes project:

- Dikes and levees may include relevant technical and social functions, such as urban development, commercial or residential development, infrastructure and transport, economic or agriculture use, intensive touristic use, uses for nature or landscape conservation, and active or passive use for energy production.

- A multifunctional dike may increase the level of flood protection and reduce the probability of dike failure. This may be realised through qualitative and/or quantitative improvement of sealing elements or the reduction of overtopping risk, etc.

\section{State of research and development}

The most comprehensive document about dike construction, the International Levee Handbook (CIRIA 2013), directly addresses dike multifunctionality in chapter 3, including access and transportation, recreation, agriculture as well as environmental and ecological improvement. The descriptions, however, are restricted to few existing, common multi-uses. The issue of transportation includes the combination of flood protection and roads and/or railway tracks. The recreation aspect is basicly limited to pathways (e.g. for cyclists) and the general recreational use of dike embankments. Common agricultural uses are grazing animals (usually sheep that are also a measure of dike maintenance), and in some cases the use of no-till crops on berms. The environmental functions are most comprehensively described, including the protection of environmentally sensitive sites, the enhancement of environmental attributes of dikes, the protection of endangered species, noise attenuation and aesthetic aspects. In addition, there is information about associated structures such as crest walls, embedded walls, pipes, conduits, culverts and spillways in chapter 9.

In Europe, only the Netherlands have identified the multifunctionality of dikes to be an important research topic so far, particularly for their river deltas. Here, multifuncionality is defined even wider and more innovative than in the existing standard literature. Research approaches and feasibility studies have been prepared; however, as yet only in national programmes as parts of the adaption strategies to climate change. Beyond this, the topic has received only little scientific attention.

Van Loon Steensma et al. (2014) describe the development of new flood protection concepts to adapt the existing flood defences along the Dutch Wadden Sea coast. In built-up areas multifunctional dikes are considered. These constructions are described as robust and to offer space for secondary functions. Furthermore, Van Loon Steensma and Vellinga (2014) sum up possible functions, benefits, drawbacks, opportunities and threats for robust and multifunctional flood defences in riverine areas of the Netherlands.

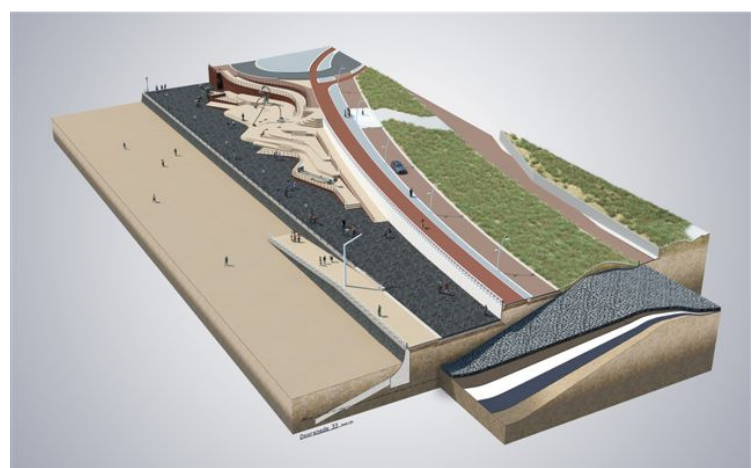

Fig. 1. Schamatic illustration of the Scheveningen Boulevard over the hidden dike (Nieuweboulevard 2016)

Different types of multifunctional dikes are presented by Schelfhout (2012):

- Spacious dike typologies

(park dike, wave breaker, climate dike, standard dike), and

- Compact dike typologies

(dike plus sheet pile on the water side, dike plus sheet pile on the land side, cofferdam, quary wall).

Moreover, several development strategies are presented by Schelfhout (2012) to meet the diverse interests of the water retaining function and other functions in the frame of the management zones of flood defences.

The Scheveningen Boulevard was implemented as a pilot project (Den Haag 2013). This $2 \mathrm{~km}$ long construction combines the primary function flood protection with the secondary functions recreation and tourism. Within five years (2009-2014) a dike-in-boulevard was created (Pleijster, van der Veeken 2014). In this construction several flood protection systems are combined:

- A flood wall reinforced with

- A hidden dike, and

- A wide beach on the sea side to reduce the wave impact on the flood protection structures during high waters.

The boulevard integrates all flood protection structures and hides the dike construction. In addition, the boulevard follows the historical coastline and offers a lot of space for cyclists, skaters and pedestrians (Fig. 1).

In Japan huge dikes were constructed under the names gentle-slope-levees or super-dikes. These constructions were primarily built to increase the earthquake resistance next to flood protection, but also to counteract the shortage of space (McKean 2013; SeaCity2100 2009).

The Institute of Soil Bioengineering and Landscape Construction of the University of Natural Ressources and Life Sciences BOKU in Vienna (Austria) has been investigating the influence of wood and undergrowth structures on the stability and maintance of dams and dikes since 2007 (BOKU 2010). The additional ecological function of diverse vegetation was investigated particularly regarding dike stability aspects. 


\section{Multifunctionality}

During the MultiDikes kick-off meeting, different possibilities for dike multifunctionality were discussed. Among other ideas, the distinction of different "multi"categories is helpful (Pohl 2015). Multifunctional dikes can consist of multiple structures and multiple materials to serve multiple functions, there are additional loads to be considered for additional functions (multiple loads) and additinonal standards and regulations need to be included in the design (multiple standards). As a result, multifunctional dikes can serve multiple uses, be located on multiple/different sites and be combined to multiple flood protection systems. This leads to innovative ideas for new functional combinations to serve future needs on and near dike constructions.

\section{MultiDikes project objectives}

\section{MultiDikes preparatory project}

The objectives of the MultiDikes preparatory project are, to

- Create a network for cooperation in the field of multifunctional dikes and to

- Apply for a European INTERREG or research project in a suitable call to start European cooperation and research on the topic of multifunctional dikes.

The first objective has already been addressed in creating a prospective project consortium with approximately ten partners from at least six EU member states (Germany, Czech Republic, Poland, Austria, Italy, and Netherlands). However, for future collaborations on different research aspects in this field, additional network partners are looked for. As yet, the participating experts come from various disciplines including geotechnics, coastal engineering, hydraulic engineering, soil bioengineering, landscape construction, and environmental sciences. A vital issue in European cooperation on a flood protection topic that crosses borders of existing legislation is the involvement of public authorities and municipalities.

As for the second objective, a proposal will be submitted for the second call of the Interreg Central Europe Programme 2014-2020 (due June 2016). The decision on approval is expected in the second quarter of 2017. In addition, a Horizon 2020 application is envisaged with a larger consortium, provided that an appropriate call will be open until 2017.

\section{MultiDikes INTERREG proposal}

The project objective of a first Interreg proposal is to

- Develop a European handbook for multifunctional flood defences to induce innovation and to determine the research needs for unsolved problems.

This handbook will serve as a recommendation for future projects in which additional dike functionality is considered. In addition, the handbook will serve as a source of information about the possibilities of dike multifunctionality, beyond the information given in the International Levee Handbook.

The handbook will contain

- Information on flood defence systems and dike construction technologies among the project area, including both technical and legal aspects,

- Possible combinations of functions, subdivided into (i) strategies, (ii) traditional flood defences (dikes), (iii) multifunctional flood defences (dikes), and (iv) responsibilities and stakeholders (national, regional, local),

- Information on assessment frameworks, costs, and benefits.

Interreg is a useful cooperation scheme for this first step to describe the fields of investigation. The transnational character of the project helps to define European approaches to dike multicunctionality, in spite of the legal restrictions and therefore little practical experience in the single countries.

Relevant institutions interested in project collaboration on the topic of multifunctional dikes either in the Interreg or Horizon 2020 programmes are welcome to get in touch with the authors.

\section{Geotechnical aspects of dike multifunctionality}

When multifunctional dikes are considered, there are a variety of important geotechnical aspects. The stability of a dike construction needs to be proven regarding additional loads by buildings, infrastructure or vegetation:

- The influence of the interaction between dike and integrated structure (construction, vegetation, etc.) on the dike stability,

- The influence of alternative dike construction materials and/or integrated structures on seepage development,

- The influence of installations and constructions on internal erosion,

- The change of resistance against surface erosion due to the use of alternative construction materials, vegetation and/or the integration of structural elements or

- The influence of unconventional dike geometries on different geotechnical aspects.

\section{Conclusions}

Dike multifunctionality is generally a historic topic, since dikes have always served different (common) functions. Still, dikes are legally restricted to serve their primary function and the inclusion of secondary functions is often difficult or even impossible to achieve. In the context of climate adaption, ecological development and urban development, new concepts to deal with areas formerly restricted to the flood protection function are coming into focus to serve for additional functions. Therefore, the concept of multiple dike functions should be discussed and rethought by all relevant stakeholders, 
particularly those working in legislation and administration, in research and in the planning sectors.

\section{References}

BOKU 2010. Projekt Gehölzstrukturen an Dämmen und Deichen [online]. Institute of Soil Bioengineering and Landscape Construction, University of Natural Ressources and Life Sciences in Vienna [cited $16 \mathrm{Au}-$ gust 2016]. Available from Internet: http://www.baunat.boku.ac.at/iblb/forschung/schwerp/ iblb/projekt-gehoelzstrukturen-an-daemmen-und-deichen (in German).

Den Haag. 2013. Nieuwe Boulevard Scheveningen [online]. City Den Hague [cited 16 August 2016]. Available from Internet: http://www.denhaag.nl/home/bewoners/to/NieuweBoulevard-Scheveningen-11.htm

CIRIA. 2013. The International Levee Handbook. DWA-M 50E, Part 12011 [online], [cited 16 August 2016]. Available from Internet: www.leveehandbook.net

McKean, C. A. 2013. Tokyo building enormous "Super-levees" to hold back its river [online], [cited 16 August 2016]. Available from Internet: http://nextcity.org/ daily/entry/tokyo-isbuilding-enormous-super-levees-to-hold-back-its-river

Nieuweboulevard [online]. 2016. Via Wikimedia Commons [CC BY-SA 3.0] [cited 16 August 2016]. Available from Internet: http://creativecommons.org/licenses/by-sa/3.0
Pleijster, E.-J.; van der Veeken, C. 2014. Dutch dikes. $1^{\text {st }}$ ed. Rotterdam: nai10 publishers.

Pohl, R. 2015. MultiDikes, in Presentation in the MultiDikes Kick-off Meeting, 15 December 2015, Rostock, Germany.

Saathoff, F.; Cantré, S.; Sikora, Z. 2015. South Baltic guideline for the application of dredged materials, coal combustion products and geosynthetics in dike construction [online], [cited 16 August 2016]. Available from Internet: http://www.dredgdikes.eu

Schelfhout, H. A. 2012. Robust and multifunctional flood defences, in $12^{\text {th }}$ Baltic Sea Geotechnical Conference, 30 May - 1 June 2012, Rostock, Germany.

SeaCity2100. 2009. Tokyo's super-dikes [online], [cited 16 August 2016]. Available from Internet: http://www. seacityresearchnet.com/archives/tag/adaptation

Van Loon-Steensma, J. M.; Vellinga, P. 2014. Robust, multifunctional flood defenses in the Dutch rural riverine area, Natural Hazards and Earth System Sciences 14: 1085-1098. http://doi:10.5194/nhess-14-1085-2014

Van Loon-Steensma, J. M.; Schelfhout, H. A.; Vellinga, P. 2014. Green adaptation by innovative dike concepts along the Dutch Wadden Sea coast, Environmental Science \& Policy 44: 108-125.

http://dx.doi.org/10.1016/j.envsci.2014.06.009 